\title{
Alighting the Milkmen, Bridegrooms, and Vagabonds: On Capital and Language ${ }^{1}$
}

\section{Graeme Webb}

School of Communication

Simon Fraser University

\begin{abstract}
From the "thunderous denunciations" of mass culture by the Frankfurt School to the ambivalence of Habermas towards mass media, it has been argued that we have moved from culture-debating to culture-consuming publics (Peters, 1993). We have abandoned the coffee house in favour of grumpy cats and lulz. Furthermore, our societal damnation has only been reaffirmed and deepened by a move towards a form of cognitive capitalism. Berardi (2011) and Marazzi (1994), in their respective work on the politics of the language economy, have suggested that cognitive capitalism has given life to a new form of crisis; the crisis of capital today is not merely economic, it also a crisis of the social imagination, and language and discourse is political. It can be enclosed by capital. However, to stop our analysis there is not only pessimistic but also fails to see the emancipatory potential within language and our media systems. Although language and discourse can be enclosed by capital, I would argue it can never fully be co-opted. While media, especially the online sphere, are full of obfuscating pomp and trolling harangues, there remains a potential critical spark in the culture and poetry of everyday language. Echoing Stuart Hall, it is the extent to which popular culture and technology are sites of contestation and the degree to which they can be mobilized to destabilize systems of domination that they matter: "Otherwise, to tell you the truth, I don't give a damn about it" (Hall, 1998). This paper will investigate the critical spark that language and popular culture can offer in an era of cognitive-capitalism-and who knows, maybe we'll have a few lulz along the way.
\end{abstract}

\section{Keywords}

Technology, language, culture, cognitive-capitalism

One of the surprising parts of conducting academic research are the theoretical tangents you end up pursuing. This paper, at its most un-presupposing, represents the work that came out of just such a tangent-a fun few weeks in the spring of 2014 when I studied Marxist poetry. In its more ambitious moments, however, I believe that there are interesting insights about what constitutes the poetry of the everyday and whether such poetry can facilitate the development of semiotic strategies of change and dissent.

So much of our labour today happens beyond the proverbial walls of the factory; we create value in the memes we make and the posts that we share. And just like the factory floors of $19^{\text {th }}$ century England, where song was used to maintain time as labourers worked, our immaterial labour is not devoid of song and poetry. Indeed, much of our online immaterial labour on new media is song and poetry-from 140-word tweets to YouTube videos, we produce and consume cultural content at a miraculous pace. And while such song and poetry may simply seem like the banal tune to which we labour online, this cultural content can also be subversive. As Eugene Genovese (1974) demonstrated so elegantly in his important work Roll, Jordan, Roll: The World the Slaves Made, even when culture is used to assure compliance (as was the case in the American South, where religion was initially used to legitimize class and racial rule), these practices can be rejected and subverted. The gospel song today is no longer a tool of white control, but one of black empowerment.

In Constituents of a Theory of the Media, Hans Magnus Enzensberger (1970) suggested that "capitalism alone benefits from the Left's antagonism to the media" (p.19). In essence, new productive 
forces have to be leveraged if a revolution is to succeed. How then can our present-day immaterial labour be leveraged? The answer, or at least part of the answer, rests with a poetry of the everyday. It is nearly impossible not to scoff after such a statement, but there remains an important kernel of truth here. There is a radical potential of online popular culture to be a tool of subversive empowerment. What we share on the "Internetz" - while sometimes banal-can and should be seen as taking the ordinary and "making it strange." In the messages that we post and the memes that we share, we are a public at play; it is a poetry of the everyday. This is our gospel music. While we must think and talk about reinvigorating labour movements and organization on the ground, we must also develop semiotic strategies of change and dissent. Our social imaginary needs to be reinvigorated. And what better place to start than the everyday?

This is not to say that all online cultural content is poetic in the way that I am suggesting. Indeed, when we consider the online corporate media messaging that we consume on a day-to-day basis, some of these cultural artifacts seem markedly un-poetic. ${ }^{2}$ Unfortunately, it is not always easy to distinguish between autonomously produced cultural content and the ideologically charged equivalents that seep into our electronic communities. However, I suggest that while it can be difficult to distinguish between these two types of content, it is also not impossible; anecdotally, we know the difference between another Buzzfeed video about millennials and content that is autonomously produced. Furthermore, cultural content is not something that is static. In other words, autonomously produced content can be co-opted by capital (we see this every day) but ideologically charged content is also fluid.

Culture is a process, not a fixed set of interpretations or practices. Even cultural content that is markedly un-poetic can and does provide an opportunity for dissent and making strange. Citing Glenn Stillar (1998), David Goodwin (1999) suggested that reading and viewing with opposition:

"reveals and calls into question the discursive means by which images offer viewers 'fictitious integrations' designed to inculcate 'apathy.' That is, criticism should goad us toward understanding 'the very real, contested, and inequitable divisions of the social order' strategically displaced in practices of everyday texts" (p. 110).

Reading and viewing cultural content with opposition is not always an easy task. Indeed, it takes a critical awareness of the cultural content that we consume. However, by contesting the markedly un-poetic, or semio-capitalism as we will momentarily investigate, we open up spaces of critique.

Language is a political technology (Marazzi, 1994/2011). The way in which this political technology is deployed depends greatly on the political and economic order. While in the Fordist economy, communication and production were juxtaposed, today, in the Post-Fordist economy, they overlap; what we see within Post-Fordism is the "coincidence of the communicative and of the productive act" (Marazzi, 1994/2011, pp. 30-31).

Language is simultaneously shaped by and shapes our political and economic reality-they cocreate one another. It is, according to Bakhtin (1981), socio-ideological. Within Post-Fordism, we have a "speaking" and "communicating" production process (Marazzi, 1994/2011) p. 23); a type of language that produces political and economic organization and also acts as a disciplinary structure. In particular, language becomes, in the words of Marazzi, "lithe," "agile," and "aimed at a precise goal;" it is, in essence, "logico-formal language." Language is not a liberal technology of the democratic public sphere nor a tool around which the working class can adhere, but a form of information and data. In Foucauldian terms, capital and language have produced a set of rational boundaries which define our cultural horizon; language is not something that is merely expressive, it is also repressive. Within this reality, the prospect of irreversibility is replacing the prospect of subversion. We must begin to rethink Marxism from this perspective: 
"the incorporation of techno-linguistic automatisms produced by semio-capital has produced a form that is not an external domination that acts on the body, but a mutation of the social organism itself" (p. 9).

Human activity, especially collective semiotic activity, has become transcodified by the economy: "the word is no longer a factor in the conjunction of talking effective bodies" (Marazzi, 1994/2011, p. 19). In essence, Post-Fordism is defined by a semio-capitalism that has effectively frozen the affective potency of language.

An examination of language within a capitalistic system must recognize its ideological nature lest our pursuit of the emancipatory spark of language be lost in a Habermasian voluntarism (the doctrine that the will is a fundamental or dominant factor in the individual or the universe) and political naiveté. Berardi (2012) has suggested that our society is undergoing a deep crisis, but that it is "much more a crisis of social imagination than mere economics" (p. 7). Our struggle today is situated within language (Marazzi, 1994/2011).

Berardi (2012), in The Uprising: On Poetry and Finance, wrote that poetry, as language's excess, could not be reduced to information. It is to poetry then that he believed we must turn as it allows for - "a new common ground of understanding and shared meaning: the creation of a new world" (Berardi, 2012, p. 147). While language is infinite, it operates within finite conditions of history and existence-poetry, for Berardi, is the reopening of the indefinite. Like Guattari's (1992) concept of "chaosmosis" (the process of going beyond the limit world), there is an ability to go beyond the semiotic limit - a redefinition of language and, therefore, a move towards an experimental world. While digital capitalism has created a closed linguistic world, acts of poetic language can "give us the ability to create a new human condition" (Berardi, 2012, pp. 156-157).

There is an appeal to the idea of poiesis as a way by which we can enact change in the world. Hemmed in by everyday discourse that is given meaning through hegemonic articulation, we need an alternative way forward. And poetry and art can help to bring about material change in the world. There is a need to take up aesthetic theory and the project that embraces the transfiguring potential of art: "[t]he highest mission of art is to metamorphose the real. Practical actions, including techniques, modify the everyday; the artwork transfigures it" (Lefebvre,1998, p. 83).

But, two thoughts now arise. One, how do we operationalize acts of poetic language to create social change or revolution? I am, to put it mildly, highly skeptical that a poem-or even a whole sonnet-can change the world. And two, poetry does not exist outside of the social. To think otherwise is to ignore the way in which aesthetics is culturally created, that the poetry that is published in a book or posted online is a part of a system of production, or that poets themselves aren't cognitive labourers. To the extent that poetry has not been captured by capital-after all, while poetry is a part of the productive process it is hardly the work of the ruling class (what does big business care of poetry?) - it has been culturally distanced from the everyday; if poetry is to be seen as being 'outside,' it is outside of the everyday. George Thomson (1946), in his brief work Marxism and Poet$r y$, wrote that our contemporary poetry has lost its vitality. It has become:

"[the work] of a small and isolated section of the community, the middle-class intelligencia, spurned by the ruling class but still hesitant to join hands with the masses of the people, the proletariat, who alone have the strength to break through the iron ring of monopoly capitalism. And so bourgeois poetry has lost touch with the underlying forces of social change. Its range has contracted-the range of its content and the range of its appeal. It is no longer the work of a people, or even of a class, but of a coterie. Unless the bourgeois poet can learn to reorientate his art, he will soon have nobody to sing to but himself" (p. 58). ${ }^{3}$ 
We do not live poetry in our everyday lives. To the extent that poetry has been captured by capital, especially as a work of cognitive labour, and the way in which it has become something unrelatable to the everyday, we have been distanced from the metamorphose that poetry offers.

Despite these points, I do not believe that this should or must mean that we abandon the spark which poiesis can offer-our project must be to find and see ways in which we can bring poetry back into the everyday. It is only in doing this that we can begin to mobilize its promethean spark and re-invigorate our social imaginary-this must be our semiotic strategy. And it is here that we must turn to online popular culture.

There is a long tradition within the Left to critique popular culture or to see online activity as being completely foreclosed upon (i.e. in terms of emancipatory political potential). From the "thunderous denunciations" of mass culture from the Frankfurt School to the updated dismissals offered by Jodi Dean (2005) and Christian Fuchs (2010), it has been argued that we have moved from culture-debating to culture-consuming publics (Peters, 1993). It is this strain within leftist critiques of technology that Matt Greaves (2015) refers to as a foreclosure politics. Like Greaves, I believe that we cannot stop at the shuttering of the potentiality that these communicative technologies offer-a new theoretical direction must be sought. It is my contention that it is in the everyday banal popular culture of memes and "Internetz" language that an opportunity presents itself.

Like Swingewood (1977), Bakhtin (1984), or Hall (1998), I believe that low/popular/folk culture can still be an emancipatory tool within a system dominated by mass culture. I do not want to overstate my enthusiasm for this possibility-I am far from holding my breath. However, to wash our hands of all popular culture, as is the pessimistic form common on the Left (and seen in the works of Mills and Adorno and Horkheimer), is unhelpful. While Marcuse (1991) did allow for the possibility that our one-dimensional totalitarian system could be challenged, our ability to arrive at these new modes of realization was severely hampered by the forces of domination-in the guise of socio-linguistic concepts of affluence and liberty-which "integrates all authentic opposition [and] absorbs all alternatives" (p. 11).

What is needed is a more productive way of conceptualizing popular culture. Such a new conceptualization must not blindly ignore the relationship between capitalism, communication, and culture, nor should it blindly follow the fatalist approach of these left leaning scholars-who, trapped by their own cultural horizon, were too eager to embrace their negative mythologies.

Bakhtin (1984) emphasized the revolutionary nature, potential, and value of traditional folk culture and humour. In the prologue to the 1984 edition of Rabelais and His World, Holquist wrote that: "Bakhtin, like Rabelais, explores throughout his book the interface between a stasis imposed from above and a desire for change from below, between old and new, official and unofficial" (p. xiv). This interface is clearly seen in what is arguably the most productive concept mobilized by Bakhtin - the carnival. The carnival existed as a space outside of the official world-a "utopian realm of community, freedom, equality, and abundance" (Bakhtin, 1984, p. 9). By examining concepts of laughter and the grotesque, he showed how a folk public sphere within the medieval marketplace was able to challenge officialdom and the status quo; that traditional folk culture was not merely a conservative impediment to progressive change or something that could ever be fully coopted, it was revolution itself.

Hall (1998) believed that the starting point for understanding popular culture was that it is, and has been, a site of "continuous struggle" (p. 442). This continuous struggle occurs between the forces of capital that seek to contain the popular classes within a new social order oriented around capital and the popular classes that seek to resist this foreclosure. Traditionalism is often mobilized by the popular classes as a form of push-back against the re-formation and re-education offered by capital. Tradition then is not merely a blind conservative value of past prejudices (though it can be-and we see this clearly in the many grossly problematic elements of popular culture), but rather a site used to enunciate a pre-capitalistic cultural form (e.g. Bakhtin's carnival). However, contemporary society has seen much (if not all) of the autonomous, 'authentic' layer of working class 
culture erased by a "social imperialism" whereby culture became a tool of capital, a form of cultural production and re-production (Hall, 1998, p. 444-446). In the end, Hall (1998) developed a conception of popular culture polarized around a cultural dialectic in which there is an ongoing tension and process of becoming; all cultural forms are contradictory, composed of antagonistic and unstable elements. In such a view, popular culture should not be dismissed nor ceded unnecessarily (e.g. the Frankfurt School); rather, we need to see it as a place "where socialism might be constituted" (Hall, 1998, p. 453).

While the way forward - towards the constitution of an independent public and popular culture remains unclear, it is possible to point certain axes that may be mobilized in such a project. The technologies of mass society and of the culture industry that had emerged by the mid-20th century do today offer a particular rationale that has helped to shape our cultural horizon-a horizon dominated by the culture industry. However, this outcome was not necessarily determined. Technology is something that is contested (Feenberg and Bakardjieva 2004).

Despite the degree to which the emancipatory potential of old communication technologies has been foreclosed upon, it does not necessarily follow that new media technologies will follow this same route. While the rationale that these new technologies help to establish is partially a function of the structuring of the economic system, they also help to disrupt sites of authority and help to create new centres of power. Hope yet remains.

There are a number of studies (e.g. Simco, 2012) that have compared online popular culture to a Bakhtinian Carnivalesque and this can provide an entry point into reinvigorating a cultural Marxism that has been lacking from the works of many political economy communication scholars. While this approach does have its strengths, I am loathing to rely too heavily on this theoretical lens for three reasons. One, the Carnivalesque is a largely utopian view of folk culture and while the utopian is invigorating, it also means the concept has limited applicability as a semiotic strategy. Two, by its very nature, the Carnivalesque remains outside of the everyday. It is something that exists as a state of exception to the social order. As a state of exception, it does provide a critical distance and an enormous space within which the status quo can be ridiculed and critiqued. However, this distance, as being outside of the everyday, limits its ability to influence our subjectivity. And three, I am uncertain that the idea of the Carnivalesque gives us the intellectual space to adequately call out the serious problems with our everyday online popular culture. And there is a lot wrong with it: from the homophobia present in the everyday language of 4chan; to the misogyny of redditors, men's rights activists, or forums devoted to pick-up artists; and the racism of lolCat speak. At its best, the idea of online popular culture as having carnivalesque spaces and elements provides a way to re-conceptualize banal and grotesque online behaviour as turning established conventions on their head. However, at its worst-in the way in which its traditionalism reinforces misogyny, racism, and homophobia-I am uncertain to the extent to which it offers the potential for a revolutionary moment as opposed to an act of catharsis or strengthening of the status quo.

It is more toward Stuart Hall, and his notion of popular culture as being polarized around a cultural dialectic, that we must turn. The contradictory, antagonistic, and unstable nature of popular culture creates opportunity and space for new forms of political participation-while also allowing us to be critical and to check our privilege. This is not the political participation derided by Jodi Dean, but rather the participation-through-other-means hinted at by Darin Barney in Excuse us if we don't give a fuck (2010). Whereas Dean has been hyper-critical of communicative capitalism and of the possibility that it can offer spaces or impetus for revolutionary change, Barney suggests that shrinking political spectrum in traditional politics (while in itself problematic) and the disenfranchisement of many youth has forced politically-active millennials to think about participation in new ways-often through autonomous online popular culture. It is in these new forms of popular cultural antagonisms that I believe the concept of poetry can be re-injected into the everyday. 
In particular, our semiotic strategy must be one of "making strange". Fred Wah (2000), drawing on the work of Viktor Shlovsky, introduced this term as he worked through his own experiences as a poet, academic, and activist:

"The technique of art is to make objects 'unfamiliar,' to make forms difficult, to increase the difficulty and length of perception because the process of perception is an aesthetic end in itself and must be prolonged. Art is a way of experiencing the artfulness of an object; the object is not important."

Poetry, by making objects unfamiliar-making strange-helps to reinvent and renew our perceptions of both the objects and our social reality that otherwise might be reified.

The idea of making strange is very similar to Paul Ricoeur's (1975/77) characterization of the function of a metaphor as a discursive categorical transgression. It is a calculated error which "disturb[s] a whole network by means of an aberrant attribution"; it is a way to "rediscover reality" (pp. 21-22). It is my belief that we have not lost our sense of poetry, but rather it has been taken from us and misinterpreted, thus losing its power and appeal (Thomson, 1946). Online popular culture is our way of reclaiming the poetic and in the process re-imagining participation and hopefully reopening our discursive imagination. In essence, we are given free rein to make strange.

Poetry in an age of communicative capitalism unites pictures, words, video and music; it is argumentative, antagonistic, funny, contemplative and down-right confusing; it stretches and alters communication and the socio-ideological by taking an enclosed and co-opted popular culture and "making strange". Whether it is "I can have Cheeseburger Cat" espousing Marxist ideas, to the "saving room for cats" Tumblr, to humorous, but pointed takes on the ways in which men feel entitled to space on public transit, or the online response to men that say "not ALL men" are misogynists or rape-the poetry within the everyday is being reinvigorated by online popular culture.

This is but a barest glimpse of a theoretical start in devising a cultural studies approach to semiotic strategies within cognitive capitalism. But echoing Hall (1998), it is the extent to which popular culture and technology are sites of contestation and the degree to which they can be mobilized to destabilize systems of domination that they matter. "Otherwise, to tell you the truth, I don't give a damn about it" (p. 453).

\section{Notes}

1. Hans Magnus Enzensberger has been a provocative commentator on, and of, our time. While many communication theorists will be familiar with his academic writing, they may be less familiar with his prose. However, part of the title of this working paper/post-tangent writing piece come from his poem Utopia which remains one of my favorite pieces of Marxist poetry.

2. Thank you to my reviewers for this turn of phrase.

3. It is worth noting that Thomson, perhaps by dint of the time he was writing in, omits much about radical poetry which is not clearly easy prey to charges of inaccessibility or disinterest in connecting with the repressed and disenfranchised. However, while these strong poetic voices do exist they are by no means mainstream. This is not a failure of artistic and expressive talent, but rather a recognition that the modernist canon in English-language poetry has tended to repress a diverse lineage of radical poetry combined with a conservative stigmatization of the liberal arts and culture. If I was to continue to work on this paper this would be an area to investigate more rigorously. 


\section{References}

Bakhtin, M. (1981). The Dialogic imagination: Four essays (M. Holquist, Trans.). Austin: University of Texas Press.

Bakhtin, M. (1984). Rabelais and his world (H. Iswolsky, Trans.). Bloomington: Indiana University Press.

Barney, D. (2010). "excuse us if we don't give a fuck": The political career of participation. Jeunesse: Young People, Texts, Cultures, 2(2), 138-146.

Berardi, F. (2012). The uprising: On poetry and finance. Los Angeles: Semiotext(e).

Dean, J. (2005). Communicative capitalism: Circulation and the foreclosure of politics. Cultural Politics: An international journal, 1(1), 51-74.

Enzensberger, H. M. (1970). Constituents of a theory of the media. New Left Review, 64, 13-36.

Feenberg, A., \& Bakardjieva, M (2004). “Consumers or citizens? The online community debate”. In A. Feenberg \& D. Barney (eds.), Community in the digital age: Philosophy and practice (pp. 1-27). Lanham, MD: Rowman \& Littlefield.

Fuchs, C. (2010). Labor in informational capitalism and on the Internet. The Information Society,26(3), 179-196. doi:10.1080/01972241003712215

Genovese, E. D. (1974). Roll jordan, roll: The world the slaves made. New York: Pantheon Books.

Greaves, M. (2015). The rethinking of technology in class struggle: Communicative affirmation and foreclosure politics. Rethinking Marxism, 27(2), 195-211. doi:10.1080/08935696.2015.1007792

Goodwin, D. (1999). Toward a grammar and rhetoric of visual opposition. Rhetoric Review, 18(1), 92-111. doi:10.1080/07350199909359258

Hall, S. (1998). Notes on deconstructing 'the Popular'. In J. Storey (ed.), Cultural theory and popular culture: An introduction (6th ed.) (pp.442-453). New York: Pearson.

Holquist, M. (1984). Introduction. In M. Bakhtin, Rabelais and his world (pp. 1-58). Bloomington: Indiana University Press.

Lefebvre, H. (1988). Toward a leftist cultural politics: Remarks occasioned by the centenary of Marx's death (D. Reifman, Trans.). In C. Nelson \& L. Grossberg (eds.), Marxism and The Interpretation of Culture (pp. 75-88). Urbana, IL: University of Illinois Press.

Marcuse, H. (1991). One-Dimensional Man: Studies in the ideology of advanced industrial society. United Kingdom: Routledge.

Marazzi, C. (2011). Capital and affects: The politics of the language economy. (G. Mecchia, Trans.). Cambridge, MA: Semiotext(e).

Peters, J. D. (1993). Distrust of representation: Habermas on the public sphere. Media, Culture \& Society, 15(4), 541-571. doi:10.1177/016344393015004003

Ricœur, P. (1981). The rule of metaphor: Multi-disciplinary studies of the creation of meaning in language (R. Czerny, Trans.). Toronto, ON: University of Toronto Press.

Simcoe, L. (2012). The Internet is serious business: 4Chan's /B/ board and the lulz as alternative political discourse on the Internet. MA Thesis, Ryerson University. Retrieved from Ryerson's online repository.

Swingewood, A. (1977). The myth of mass culture. London: Macmillan.

Thomson, G. D. (1945). Marxism and poetry. London: Lawrence \& Wishart.

Wah, F. (2000). Faking it: Poetics and hybridity, critical writing 1984-1999. Edmonton: NeWest Publishers. 